\title{
Program Konseling Keluarga Bagi Orang Tua Yang Memiliki Anak Autis
}

\author{
Nurhastuti \\ Univiversitas Negeri Padang
}

\begin{abstract}
Unpreparedness of parents in taking care of the interests of children with autism will make children continue backward and not ready for the future. In such conditions it is necessary support for parents in caring for children with autism. This study was conducted aiming to provide support to parents of children with autism so that the problems arising from the existence of an autistic child can be minimized or even eliminated altogether. In addition, this research can also be used as a reference for parents who have children with autism in an effort to maintenance and cure children with autism. Qualitative research is considered more appropriate to determine the family counseling program for parents who have children with autism in the Autism Institute YPPA Padang. The approach used in this study is deemed appropriate in understanding and motivating parents of children with autism with all complexity as subjective beings.
\end{abstract}

Keywords: Family counseling, children with autism

\section{PENDAHULUAN}

Kondisi autisme ini mempengaruhi semua anggota keluarga terutama orang tua, kebanyakan setelah orang tua mengetahui anaknya menderita autisme, timbul perasaan bersalah atau cemas, hal ini disebabkan karena kurangnya pengetahuan mereka mengenai autisme sehingga menghadapi situasi demikian tidak jarang orang tua terutama ibu tidak tahu apa yang harus ia perbuat.

Tidak mudah memang memiliki anak dengan autisme, namun peran orang tua ataupun kelurga adalah kunci keberhasilan mendidik anak autis agar bisa menjadi mandiri. Orang tua atau anggota keluarga harus mengetahui bagaimana melakukan pendekatan dan perawatan, selain itu sebaiknya orang tua atau keluarga bekerja sama dengan dokter atau spesialis autis dalam menangani anak autisme.

Permasalahan tanggung jawab moral orang tua dalam menghadapi permasalahan pengasuhan anak autis dapat dibantu oleh berbagai propesi salah satu diantaranya oleh peran seorang konselor. Di sini konstribusi konselor dalam konseling mempunyai fungsi yaitu dalam menyiapkan, memberikan informasi tentang tempat penyelenggaraan pendidikan, serta memberikan pengetahuan kepada orang tua dalam cara menghadapi permasalahan pengasuhan bagi anaknya. Konseling dapat menyiapkan suatu lingkungan baru yang berfungsi lebih baik. 
Strategi konseling keluarga dengan pendekatan konseling humanistik merupakan salah satu konseling yang dapat diberikan kepada keluarga yang memiliki anak autis. Konseling kelurga adalah kepenasehatan keluarga secara langsung. Kepenasehatan keluarga maksudnya adalah memberikan penunjuk kesadaran dan pengertian yang berkaitan dengan problem yang sedang dihadapi oleh klien yang tidak lain berdasarkan pada ajaran agama yang dianut oleh klien. Konseling keluarga adalah upaya bantuan yang diberikan kepada individu anggota keluarga melalui sistem keluarga (pembenahan konseling keluarga) agar potensinya berkembang seoptimal mungkin dan masalahnya dapat diatasi atas dasar kemauan membantu dari semua anggota keluarga berdasarkan kerelaan dan kecintaan terhadap keluarga.

Berdasarkan fenomena tersebut, penelitian ini akan mengangkat beberapa permasalahan yang peneliti rumuskan sebagai berikut: (1) Bagaimanakah peran konseling keluarga bagi orang tua yang memiliki anak autis?, (2) Bagaimanakah konseling keluarga dapat membantu proses terapi yang dilakukan orang tua yang memiliki anak autis?.

Konseling adalah bantuan yang diberikan oleh seseorang pembimbing (konselor) kepada seseorang konseli atau sekelompok konseli (klien, terbimbing, seseorang yang memiliki problem) untuk mengatasi problemnya dengan jalan wawancara dengan maksud agar klien atau sekelompok klien tersebut mengerti lebih jelas tentang problemnya sendiri dan memecahkan problemnya sendiri sesuai dengan kemampuannya dengan mempelajari saran-saran yang diterima dari Konselor. Sedangkan arti dari keluarga adalah suatu ikatan persekutuan hidup atas dasar perkawinan antara orang dewasa yang berlainan jenis yang hidup bersama atau seorang laki-laki atau seorang perempuan yang sudah sendirian dengan atau tanpa anak-anak, baik anaknya sendiri atau adopsi dan tinggal dalam sebuah rumah tangga. Konseling keluarga pada dasarnya merupakan penerapan konseling pada situasi yang khusus. Konseling keluarga ini secara memfokuskan pada masalahmasalah berhubungan dengan situasi keluarga dan penyelenggaraannya melibatkan anggota keluarga (Pujosuwarno, 2007).

Konseling keluarga dapat dikatakan sebagai konselor terutama konselor non keluarga, yaitu konseling keluarga sebagai sebuah modalitas yaitu klien adalah anggota dari suatu kelompok, yang dalam proses konseling melibatkan keluarga inti atau pasangan (Capuzzi, 1991). Konseling keluarga memandang keluarga secara keseluruhan bahwa anggota keluarga adalah bagian yang tidak mungkin dipisahkan dari anak (klien) baik dalam melihat permasalahannya maupun penyelesaiannya.

Tahap-tahap penyembuhan dalam konseling keluarga adalah sebagai berikut (Pujosuwarno, 2007): (1) Mengembangkan hubungan baik, antara terapis dengan anggota keluarga, (2) Mengembangkan penghargaan emosional terhadap hubungan keluarga, dinamika beserta problemproblemnya, (3) Mengembangkan alternatif pemecahan masalah, (4) Menerapkan salah satu alternatif pemecahan.

Melalui konseling keluarga ini diharapkan orang tua dapat mengatasi masalah-masalah yang mungkin timbul karena anak autis, sehingga orang tua dapat mengatasi problem-problem yang melingkupinya dan mengatasi sendiri problem tersebut.

Istilah autisme dipergunakan untuk menunjukkan suatu gejala psikosis pada anak-anak yang unik dan menonjol yang sering disebut sindrom Kanner yang dicirikan dengan ekspresi wajah yang kosong seolah-olah sedang melamun, kehilangan pikiran dan sulit sekali bagi orang lain untuk menarik perhatian mereka atau mengajak mereka berkomunikasi (Budiman, 2008). Autistik adalah suatu gangguan perkembangan yang kompleks menyangkut komunikasi, interaksi sosial dan aktivitas imajinasi. Gejalanya mulai tampak sebelum anak berusia 3 tahun (Suryana, 2004).

Menurut Veskarisyanti (2008), ada beberapa klasifikasi autism, diantaranya: (1) Aloof. Anak dengan autisme dari tipe ini senantiasa berusaha menarik diri dari kontak sosial dan cenderung untuk menyendiri di pojok, (2) Passive. Anak dengan autisme tipe ini tidak berusaha mengadakan kontak sosial melainkan hanya menerima saja. (3) Active but odd. Pada tipe ini, anak melakukan pendekatan namun hanya bersifat repetitif dan aneh. 
Dalam menerima kehadiran anak dengan gangguan autisme, beragam hal terjadi pada diri orangtua. Orangtua biasanya stres, kecewa, patah semangat, mencari pengobatan keman-mana, serba khawatir terhadap masa depan anaknya dan lain-lain. Hal ini ditegaskan oleh Williams dan Wright (2004) yang mengatakan bahwa keluarga akan melalui serangkaian emosi saat dikatakan anak mereka autis. Ini bervariasi pada setiap keluarga, dan setiap keluarga punya perjalanan emosionalnya sendiri. Beberapa keluarga telah melalui proses diagnostik panjang dan beberapa harus menunggu lama waktu konsultasi. Beberapa menemukan prosesnya sangat cepat sehingga punya sedikit waktu untuk memikirkan akibatnya dari menata emosi mereka. Pada beberapa anak, diagnosis lebih mudah dibuat pada saat anak berusia dini dan pada beberapa, diagnosisnya sulit karena masalahnya lebih ringan. Semua ini dapat mempengaruhi bagaimana orangtua akan memikirkan langkah ke depan apa yang harus mereka lakukan.

Menurut Williams dan Wright (2004) semua orangtua memiliki respon dan perasaan berbeda saat anak mereka didagnosa menderita autisme. Beberapa reaksinya adalah sebagai berikut: (1) Lega, jika orangtua memahami mengenai autisme dan mengetahui bagaimana mencari bantuan ahli, (2) Rasa bersalah, adalah perasaan orangtua yang khawatir jika mereka melakukan hal yang salah selama kehamilan atau pengasuhannya, (3) Kehilangan, jika mimpi dan cita-cita bagi anak mereka sebelum lahir dan saat mereka masih kecil tidak terpenuhi, (4) Ketakutan akan masa depan, disebabkan keluarga sangat takut akan masa depan anak-anak mereka dan harus mengubah harapan akan masa depan anaknya, (5) Mencari informasi, keluarga ingin mengumpulkan informasi sebanyak mungkin dan mencari keluarga lain untuk berbagi pengalaman. Walaupun ada beberapa keluarga yang mungkin menghindar dari informasi dan mencoba tidak memperdulikannya.

\section{METODE}

Metode kualitatif adalah metode penelitian yang dipergunakan untuk meneliti pada kondisi obyek yang alami (natural), dan peneliti menjadi instrumen kunci dan hasil penelitianya lebih menekankan pada makna dari yang diteliti, daripada mengeneralisasi obyek penelitian. Metode penelitian kualitatif lebih mudah menyesuaikan dengan kondisi lapangan, lebih peka terhadap perubahan pola atau nilai dan bahkan data yang ada di lapangan. Kemudian untuk mempertajam gambaran terhadap fenomena yang diteliti, maka interpretasi langsung dari fenomena atau kejadian agar memperoleh prioritas yang tinggi dalam penelitian kualitatif daripada interpretasi terhadap pengukuran data.

Penelitian ini akan dilakukan di Lembaga Autis YPPA Kota Padang dengan jumlah orang tua yang memiliki anak autis sebanyak 13 orang tua. Penentuan lokasi penelitian ini didasarkan pada pertimbangan bahwa lokasi penelitian yang dipilih dapat mengurangi keterbatasan waktu dan dana yang dimiliki peneliti, karena lokasi penelitian mudah dijangkau. Selain itu, peneliti mudah mendapatkan akses ke lokasi penelitian sehingga memudahkan dalam pencarian data-data yang diperlukan.

Teknik pengumpulan data yang digunakan dalam penelitian ini adalah wawancara, observasi dan studi kepustakaan. Dalam penelitian ini, teknik pengolahan dan analisis data dilakukan dalam beberapa tahapan yaitu mengorganisasikan data; kategori, tema dan pola jawaban; mencari Alternatif penjelasan bagi data; serta menulis hasil penelitian.

\section{HASIL}

Penelitian telah dilaksanakan selama kurun waktu 2 bulan, yaitu antara bulan Juli 2014 sampai dengan bulan September 2014 di Lembaga Autis YPPA Kota Padang. Subyek penelitian ditentukan secara consecutive sampling yaitu dengan mendata orang tua yang memiliki anak autis sesuai dengan kriteria inklusi dan eksklusi sehingga memenuhi jumlah yang memenuhi syarat analisis. Studi ini didapatkan jumlah sampel sebanyak 13 sampel.

Berdasarkan hasil penelitian terhadap informan diperoleh hasil penelitian sebagai berikut: (1) Anak autis sering bersama ibunya dibanding dengan bapaknya. Selain karena Bapak merupakan tulang punggung keluarga yang bertanggung jawab memberikan nafkah kepada keluarga juga memang ibu lebih mempunyai kedekatan secara psikologis kepada anak-anaknya termasuk anak 
autis, (2) Orang tua yang memiliki anak autis berusia pada kisaran 26 tahun sampai 45 tahun, (3) Sebagian besar orang tua yang memiliki anak autis di Lembaga Autis YPPA Kota Padang berlatar belakang pendidikan Sarjana, (4) Mayoritas informan beragama Islam, (5) Pekerjaan orang tua yang paling banyak yaitu wiraswasta.

Dalam mengatasi problem, peneliti menggunakan pendekatan behavioral, yang disebutkan terhadap empat tahap secara berturut-turut sebagai berikut: (1) orangtua membutuhkan untuk dididik dalam bentuk perilaku-perilaku alternatif. Hal ini dapat dilakukan dengan kombinasi tugastugas membaca dan sesi pengajaran khususnya tentang asuhan terhadap anak autis, (2) setelah orang tua membaca tentang prinsip dan/atau telah dijelaskan materinya, konselor menunjukan kepada orang tua bagaimana cara mengajarkan kepada anak autis, sedangkan orang tua melihat bagaimana melakukannya sebagai ganti pembicaraan tentang bagaimana hal ini dikerjakan, (3) selanjutnya orang tua mencoba mengimplementasikan prinsip-prinsip yang telah mereka pelajari menggunakan situasi sesi terapi. Terapis selama ini dapat member koreksi jika dibutuhkan, (4) setelah terapis memberi contoh kepada orang tua cara menangani anak autis secara tepat. Setelah mempelajari dalam situasi terapi, orang tua mencoba menerapkannya di rumah. Saat dicoba di rumah, konselor dapat melakukan kunjungan untuk mengamati kemajuan yang dicapai.

\section{PEMBAHASAN}

1. Peran Konseling Keluarga Bagi Orang Tua yang Memiliki Anak Autis

Setelah dilakukan beberapa kali kegiatan konseling keluarga ditambah dengan wawancara mendalam serta observasi kepada para informan, maka dapat dijelaskan beberapa peran konseling keluarga bagi orang tua yang memiliki anak autis yaitu sebagai berikut: (1) Mengembangkan Hubungan Baik. Pelaksanaan konseling keluarga sama dengan proses konseling pada umumnya. Dalam prosesnya konseling berfungsi menolong klien mengubah keterampilannya dalam menilai potensi-potensinya, aspirasi-aspirasinya dan self-concept-nya yang sering keliru dengan pertolongan konseli. Setelah potensi-potensi dan aspirasinya terbangun untuk menyelesaikan suatu masalah maka akan sangat mudah klien membangun hubungan baik di keluarga, (2) Mengembangkan Penghargaan Emosional. Pelaksanaan konseling keluarga yang peneliti lakukan merupakan pemberian pengetahuan tentang cara yang dipakai orang tua dalam memberi perlakuan kepada anak autis. Setelah mengetahui caracara asuhan yang baik dan benar terasa pula bahwa dalam diri kebanyakan orang tua tumbuh penghargaan emosional kepada anak autisnya, (3) Mengembangkan Alternatif Pemecahan Masalah. Model konseling keluarga menjadi bisa terapkan bagi anak autis yang merasa kurang mendapatkan dukungan dan perhatian dari keluarganya. Model ini bisa mengambil bentuk family therapy atau terapi keluarga, couples therapy atau terapi pasangan dan parent education (Surya, 2003: 168). Berbagai model terapi bisa dilakukan berdasarkan kebutuhan anak autis, (4) Menerapkan Salah Satu Alternatif Pemecahan Masalah. Sangat penting karena memiliki anak Autis berarti merubah seluruh dinamika dan tujuan hidup keluarga (baik orang tua maupun saudara kandung). Dukungan seluruh keluarga sangat dibutuhkan dalam proses pemulihan.

\section{Manfaat Konseling Keluarga dalam Membantu Proses Terapi yang Dilakukan Orang} Tua yang Memiliki Anak Autis

Di pusat terapi autis, banyak cara yang digunakan oleh terapi anak autis agar tumbuh dan berkembang sesuai dengan kemampuannya secara optimal. Selain terapi-terapi yang ditawarkan, ada juga terapi lain yang perlu dilakukan untuk mendukungnya. Seperti terapi obat-obatan, terapi diet, terapi wicara, terapi perilaku, dan lainnya yang disesuaikan kebutuhan anak autis. Namun yang lebih penting adalah penerimaan dan dukungan dari keluarga untuk membimbing "ekstra", sehingga upaya keterlibatan keluarga untuk "kesembuhan" anak autis sangat dibutuhkan.

Melalui berbagai terapi, diharapkan penyandang autis dapat menjalani hidup seperti halnya anak lain yang normal dan tumbuh menjadi mandiri serta berprestasi. Namun demikian, tidak berarti terapi diserahkan pada dokter dan terapis semata, melainkan justru orang tua harus melakukan terapi dan stimulasi setiap harinya di rumah (Nakita, 2003) karena waktu keluarga untuk membimbing lebih banyak dibandingkan di tempat terapi. Keluarga 
(khususnya orang tua) lebih tahu apa yang dibutuhkan dan apa yang harus dilakukan, karena dalam lingkungan keluarga anak-anak autis dapat tumbuh dan kembang secara alami dengan suasanan kekeluargaan.

Menjadi bukti bahwa para ahli (terapis autisme) yang dimaksud, tidaklah melulu harus yang bergelar medis. Orang tua pun dapat menjadi pembimbing dan pendidik yang andal selama orang tua mau belajar, mencoba dan pantang menyerah (Sarasvati, 2004) untuk memahamai anaknya yang memiliki kebutuhan khusus.

Bimbingan keluarga adalah proses bantuan yang sifatnya adalah memandirikan, sehingga terbentuk kepribadian yang matang yaitu mampu menjalin komunikasi yang baik, mampu membedakan nilai-nilai yang pantas dan tidak pantas, boleh dan tidak boleh, kemampuan kreativitas yang senantiasa berkembang dan terlaksananya semua tugas perkembangan pada setiap fase usia, yang kesemuanya terwujud dari adanya kerjasama orang tua (orang dewasa) di dalam keluarga, meskipun kebanyakan anak lebih dekat dengan ibu.

Menurut Chaerunnisa (2008) bahwa kunci sukses untuk membantu para orangtua atau keluarga agar penderita autis dapat berinteraksi dengan lingkungan sekitarnya, maka seluruh anggota keluarga harus turut langsung membantu para penderita ini berusaha melakukan hal itu. Artinya untuk mencapai intensitas penanganan anak autis yang ideal diperlukan dukungan dan partisipasi dari seluruh keluarga (terutama ibu yang lebih berperan dalam mengasuh anak di rumah). Akan tetapi tidak semua ibu dapat berpartisipasi dalam penanganan anak autis secara khusus selama anak di rumah. Kemungkinan disebabkan oleh kurangnya pengetahuan ibu tentang penanganan autisme dan sikap ibu yang lebih menyerahkan penanganan anaknya hanya di tempat terapi (seharusnya ibu bertanggung jawab dan berpartisipasi aktif dalam penanganan anak autis di rumah).

Manfaat pelaksanaan konseling keluarga dalam membantu proses terapi yang dilakukan orang tua yang memiliki anak autis dapat dilihat dari perkembangan anak autis dalam beberapa hal sebagai berikut: (1) Perkembangan keadaan fisik yang senantiasa mengalami pertumbuhan yang akan diikuti dengan kemampuan yang semakin berkualitas sesuai tahapan perkembangan dan ketrampilan: menolong diri sendiri (seperti berpakaian, makan, mandi), menolong orang lain (seperti membantu membersihkan tempat tidur dan lantai, membantu teman yang jatuh), ketrampilan dasar (seperti membaca, menulis, menggambar, berhitung), ketrampilan bermain (seperti bersepeda, bersepatu roda, berenang), (2) Perkembangan kemampuan bahasa untuk memperluas lingkungan sosial anak. Karena komunikasi adalah kemampuan diri untuk mengerti apa yang dikatakan orang lain. Meskipun ada kosa kata rahasia dalam berkomunikasi, misalnya kode-kode, isyarat dan penggunaan jari-jari untuk mengkomunikasikan kata-kata, (3) Perkembangan keadaan emosi yang perlu dilatih untuk dikendalikan. Karena emosi yang meledak-ledak kurang diterima di lingkungan sosial. Ketenangan emosi diperoleh dari kejelasan peranan, permainan dan olah raga sebagai bentuk penyaluran emosi yang tertahan dan ketrampilan menyelesaikan berbagai macam tugas, (4) Perkembangan sikap dan perilaku moral yang dibiasakan sehingga anak-anak mulai menyadari aturan-aturan perilaku yang boleh, harus atau dilarang. Perlu kejelasan sanksi ketika melanggar aturan sehingga anak tidak akan bersikap baik dan bermoral.

Kesemua hal di atas telah dilatih melalui konseling keluarga yang bertujuan anak autis mampu tumbuh secara normal. Sehingga tujuan utama orang tua melakukan terapi terhadap anak-anak mereka yang menderita autis adalah bahwa mereka menginginkan anak-anak dapat hidup normal kembali seperti anak-anak pada umumnya yang dapat berkomunikasi secara normal. Hal tersebut akan menjadi sulit jika anak-anak mereka tidak dapat berkomunikasi secara verbal. Disadari atau tidak, pada akhirnya orang tualah yang akan menjadi tiang utama dari keberhasilan anak-anak ini. Para terapis, guru dan ahli medis adalah "penasihat" orang tua dalam mengambil keputusan dan membantu program pendidikan akademis dan sosial. 


\section{SIMPULAN}

Beberapa kesimpulan yang dapat penyusun kemukakan dalam penelitian ini adalah: (1) Peran konseling keluarga bagi orang tua yang memiliki anak autis di antaranya yaitu mengembangkan hubungan baik, mengembangkan penghargaan emosional, mengembangkan alternatif pemecahan masalah dan menerapkan salah satu alternatif pemecahan masalah, (2)Manfaat pelaksanaan konseling keluarga dalam membantu proses terapi yang dilakukan orang tua yang memiliki anak autis.

\section{DAFTAR RUJUKAN}

Capuzzi, D. (1991). Introduction to Counseling: Perspective for the 1990's. Boston: Allyn and Bacon.

Ginanjar, Adriana. S. (2008). Menjadi Orang Tua Istimewa. Jakarta: Dian Rakyat.

Kanfer, Frederick H \& Goldstein, Arnold P. (1988). Helping People Chane, A Textbook Method. New York: Perganen Press Inc.

Maulana, M. (2007). Anak Autis: Mendidik Anak Autis dan Gangguan Mental Lain Menuju Anak Cerdas dan Sehat. Yogyakarta: Katahati.

Prayitno, Prayitno; Mungin Eddy, Wibowo; Marjohan, Marjohan; Heru, Mugiharso; Ifdil, I. (2015). Pembelajaran melalui pelayanan BK di satuan pendidikan: pengembangan manusia seutuhnya. Yogyakarta: Paramitra Publishing.

Pujosuwarno, Sayekti. (2007). Bimbingan dan Konseling Keluarga. Yogyakarta: Menara Mas Offset.

Suryana, A. (2004). Terapi Autisme, Anak Berbakat dan Hiperaktif. Jakarta: Progress.

Tambunan, E.H. (2004). Orang Tua Teladan. Bandung: Indonesia Publishing House.

Veskarisyanti, Galih. A. (2008). 12 Terapi Autis Paling Efektif dan Hemat. Yogyakarta: Pustaka Anggrek.

Williams Chris dan Barry Wright. (2007). How to Live with Autism and Asperger Syndrome, Strategi Praktis Bagi Orang Tua dan Guru Anak Autis. Cetakan Pertama. Jakarta: Dian Rakyat. 